\title{
Site Suitability Analysis for Municipal Solid Waste Disposal in Birnin Kebbi, Nigeria
}

\author{
Ismail Usman Kaoje ${ }^{1}$, Ibrahim Musatapha Dankani $(\mathrm{PhD})^{2}$, Ibrahim Ishiaku ${ }^{1}$ \\ ${ }^{I}$ Department of Geography, Federal University Birnin Kebbi. P.M.B. 1157 Kebbi State-Nigeria. \\ ${ }^{2}$ Department of Geography, Usmanu Danfodiyo University, Sokoto. Nigeria.
}

\begin{abstract}
Management of solid waste is one of the challenges facing most developing countries like Nigeria where there is no substantial National Waste Management Plan. This led to the practice of open dumping system, which is not environmentally sound and socially acceptable. Considering the nature of solid waste disposal in Nigeria, there is a need to utilize techniques and technology for effective decision making in selecting appropriate site for solid waste disposal. This aim of this paper lies in management of waste at its final destination or dumping grounds with the objective of locating the most suitable site for municipal solid waste disposal in Birnin Kebbi. Remote Sensing technology and Geographic Information System Multi-criteria evaluation method were employed to perform effective site suitability analysis of the study area. Landsat 8 OLI was used to generate needed data for this research. Buffer distance analysis and overlay operation were used to evaluate site suitability criteria considered for this research. The result achieved in this study generated maps that shows better site for urban solid waste disposal/landfill in Birnin Kebbi; these may help in finding a better approach to curtail the current challenges.
\end{abstract}

Keywords: GIS, Remote Sensing, Site Suitability, Site Selection, Solid waste

\section{INTRODUCTION}

The term Municipal solid waste (MSW) is "usually applied to a heterogeneous collection of wastes produced in urban areas" (UNEP 2005 p.1), the nature of these waste varies from region to region. Nevertheless, Solid waste refers to non-liquid, non-gaseous and unwanted materials generated from residential, commercial and industrial activities in a given area. Management of municipal solid waste involves several activities which can be categorized into collection, transportation, treatment and disposal.

Municipal Solid Waste (MSW) Management is one of the problems facing many cities all over the world especially in developing countries that are faced with problems of unplanned urban growth, rapid urbanization and low economy. In Nigeria for instance, before 1950 less than $15 \%$ of the total population were living in urban areas, by 1970 it rises to $23.4 \%$ and $43.5 \%$ by the year 2000 , and it had been predicted to rise above $50 \%$ by 2010 (Ujoh, et. al, 2010). The more cities are growing, the more waste they will produce which will need more resources to manage. Apart from the above stated fact. The standards of municipal solid waste management is still poor and outdated in many developing countries, with poor documentation of waste generation rates and its composition, inefficient collection systems, poor treatment systems and disposal of municipal wastes with toxic and hazardous waste, indiscriminate disposal or dumping of wastes and inefficient utilization of disposal site space (Ayuba and Manaf 2013). Failure to pay adequate attention to solid waste management incurs severe penalty at a later time in form of resources lost and impact on public health and the environment (UNEP 2005).

Waste collection, transportation and disposal are a serious problem in major cities in Nigeria; most state and local government authorities admit their inability to cope with the problem (Ayuba and Manaf, 2013). Open dumping is the most common method of solid waste disposal in most cities. In an urban area such as Birnin Kebbi (the study area), facilities for house to house collection of solid waste is uncommon if not absent. Individuals are expected to deposit their refuse at designated points where they exist, from where vehicles can collect them for final disposal. However, there is no regular routine collection and as a result, the communal points commonly called dumps are generally at open spaces along street ends which usually becomes nuisance points to Urban dwellers (Abdullah, 2013). Waste decompose and create unhealthy odours because they are sometimes left without collection for months, provide breeding places for flies, ants, scorpions, snakes, and then papers and other light object are blown around by wind. Most of the refuse end up in the drains and thereby contribute to the pollution of rivers and drainages. Moreover, in the study area (Birnin Kebbi) the authorities concerned with solid waste management are Kebbi Urban Development Authority (Abdullahi, 2013). The organization has sole responsibility of transporting waste out of the city. Still the standard of waste management is poor. The state does not have a single permanent site for solid waste disposal. The disposal is generally on 
excavated pits. Most of these pits are made by construction companies or are created by erosion. However in all the cases no precaution is taken to protect both natural and human environment. Refuse is dumped on bare unprotected soil without proper planning. These practices can destroy the surface and the groundwater as well as the general environment. The lack of organize and effective management of municipal solid waste in Birnin Kebbi and many cities around Nigeria is attributed to lack of substantial National Waste Management Plan and lack of funds for environmental agencies to execute their activities. Therefore, there is a need to adopt techniques and technology that are cost effective and that will reduce time waste and increases accuracy in solving real world problems.

This research adopted Remote Sensing (RS) technology and Geographic Information System (GIS) techniques for selecting suitable site for municipal solid waste disposal in the study area. They are identified as the best solution in selecting environmentally safe, socially acceptable and economically viable disposal sites (Kabite, Suryabhagavan and Sulaiman 2012). RS Technology can provide up-to-date/spatial information on land-cover patterns useful as input data in the task. GIS on the other hand is useful in dump site/landfill selection due to its unique capabilities and tools of performing an integrated analysis of spatial and its attributes data to produce maps that on further analyses and field investigations can give way a number of candidate sites thereby reducing the cost and time involved in the process (Kabite, Suryabhagavan and Sulaiman 2012).

There are several stages in municipal solid waste (MSW) management, right from the stage where it is collected/generated till the waste reaches its final destination or at a stage where it is not a threat to environment and humans. It is observed that municipal solid waste management can be separated into mainly three stages. One is the waste management in the area where it is generated, second is the management of collection and transportation of waste and the last is the management of waste at its final destination or dumping grounds (Ayuba, and Manaf, 2013). However, this paper will cover the last stages which deals with the municipal solid waste management at it final destination. This includes the issues related to finding final destination site for municipal solid waste disposal in Birnin Kebbi, Nigeria.

\section{STUDY AREA}

The urban centre of Birnin Kebbi is the state capital of Kebbi State and also the administrative headquarter of Gwandu Emirate and Birnin Kebbi Local Goverment Area. As shown in figure: 1a and figure: $1 \mathrm{~b}$, the city is located in the North-Western part of Nigeria at approximately latitude $12^{0} 25^{\prime} 0^{\prime \prime} \mathrm{N}$ and longitude $4^{0} 20^{\prime} 0^{\prime \prime} \mathrm{E}$ and it has a land area of about $1385.033 \mathrm{klm}^{2}$ with a population of 268,620 according to 2006 population census (NPC 2010).

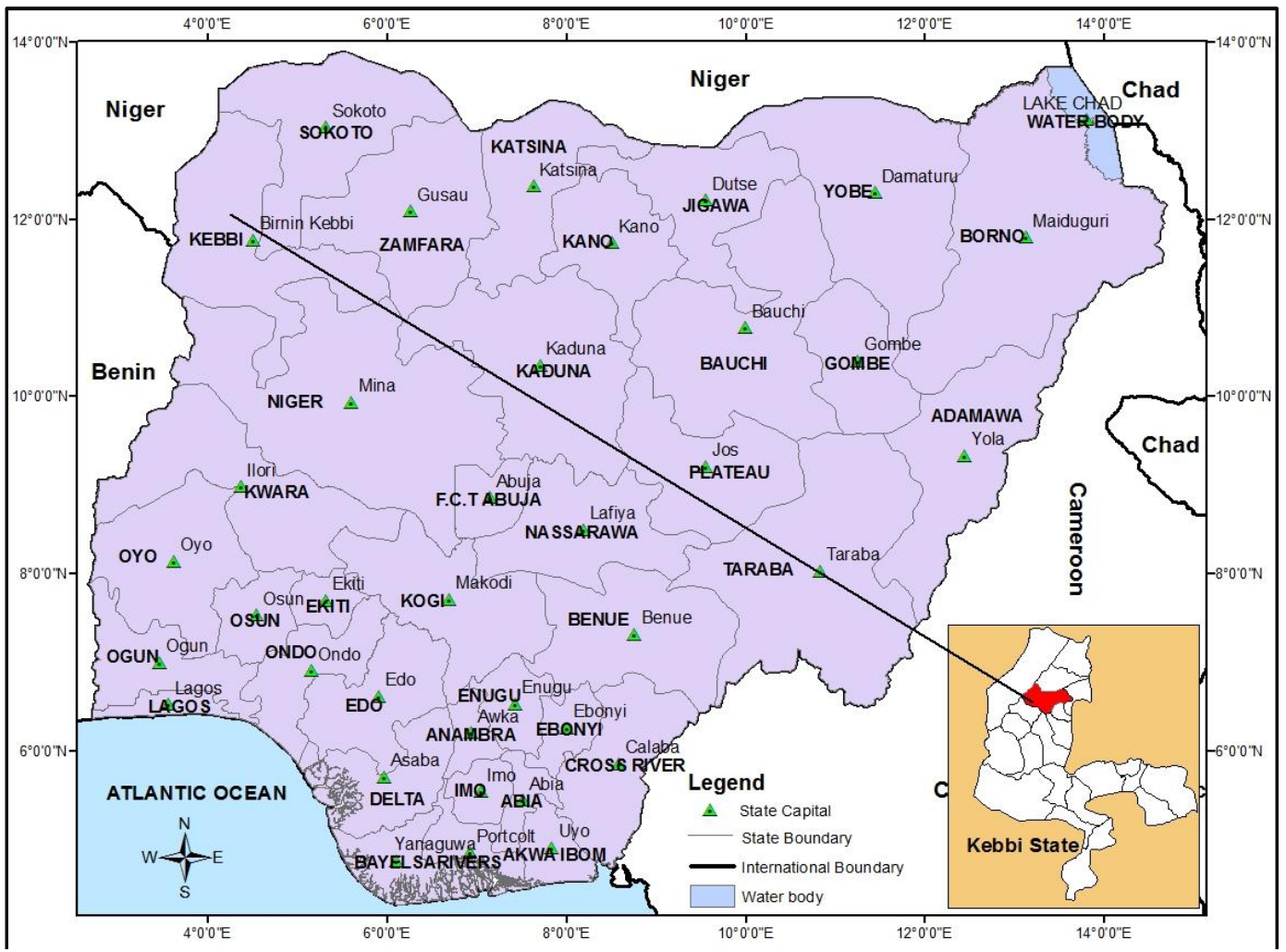

Figure 1a: Map of Nigeria showing location of Kebbi State 


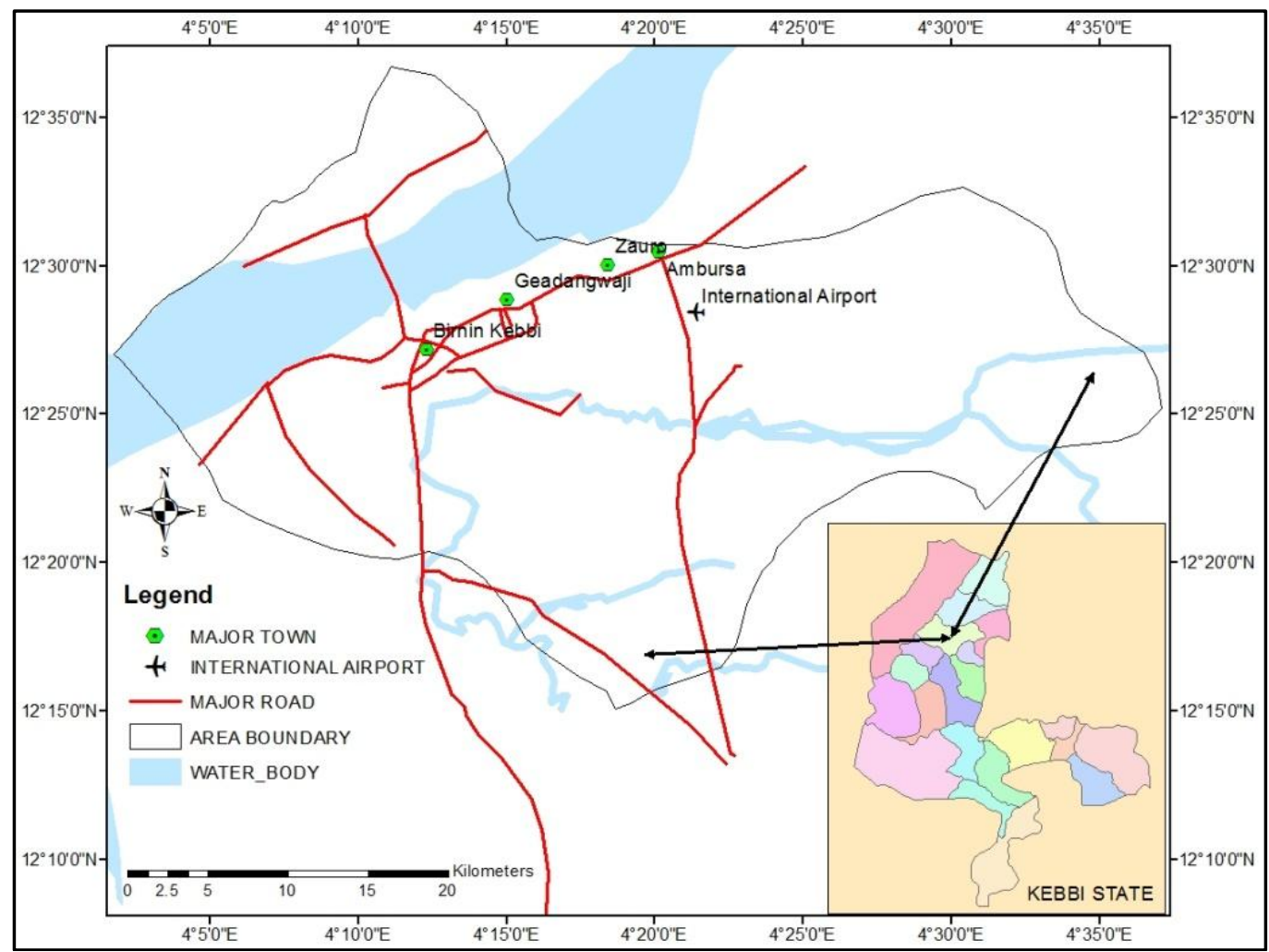

Figure 1b: Location map of Birnin Kebbi Local Government Area

\section{METHODOLOGY}

This study is interested in locating the most suitable site for municipal solid waste disposal in Birnin Kebbi, using Remote Sensing and GIS technology. To avoid harming local communities and satellite areas (villages) around the study area, the entire local government area of Birnin Kebbi is covered to successfully achieve the suitability site selection for solid waste disposal site.

For the purpose of this study, the following site selection criteria are considered for the suitable site of waste disposal/landfills in the study area. Dumps site must be:

i. 1,500 meters away from build-up areas (include parks, hospitals, markets, villages, schools, airport, sport centres, buildings and other social centres)

ii. 300 meters away from all water body (include rivers, streams, lakes)

iii. 200 meters away from all transport routes

iv. 200 meters away from forest reserve and agric lands

v. Soil with relatively low rate permeability and soil with very low permeability are considered suitable for dumps

vi. Landform that is located not on slope surfaces within the study area.

The above mentioned criteria are selected based on the UNEP 2005 guidelines. The adopted criteria must be satisfied for the most suitable disposal site.

Landsat 8 Operational land image (OLI) of March 2015 is acquired for land cover/land-use map of Birnin Kebbi L. G. A. The OLI image is used to determine the available area that can be used as a potential site for sitting the disposal point/landfill. Likewise, Shuttle Radar Topographic Mission (SRTM) data is acquired for hydrological and elevation data information of the study area. Both Landsat 8 OLI image and SRTM data (DEM 30x30m resolution) of the study area are acquired from US Geological Survey (USGS).

ArcGIS 10.1 and Erdas IMAGINE 9.2 software packages are utilize in creating and development of digital GIS data needed in carrying out accurate analysis of the above mention criteria, which provide a suitable site for waste disposal/landfills in the study area.

Summary of both GIS and Remote Sensing operation conducted in this research are itemized below:

- Creation of Multispectral Image. Landsat 8 OLI Panchromatic images of band 2 blue, band 3 green, band 4 red, band 5 NIR, band 6 SWIR and band 7 SWIR are combined using LAYER STACK tool of Erdas IMAGINE 9.2.

- Subset of the study area.

- Spectral enhancement and spatial enhancement tools available in Erdas IMAGENE 9.2 are used to enhance image display of the study area satellite imagery. 
- Supervised classification analysis is used to convert the satellite imagery of the study area in to thematic information that is used in GIS for multi-criteria analysis.

- Vectorization: this operation allows the conversion of Raster thematic images to Vector data.

- ArcGIS Buffer tools are used to determined and identify restricted areas for disposal site.

- Digitization of geological map of Birnin Kebbi that was acquired from the work of Nkwunonwo, U. C. and Okeke F. I. 2013.

- Convertion of Digital Tarrain Model (DTM) in to Triangular Irregular Network (TIN)

- Overlay of restricted (buffered maps) areas on geological map and elevation map to produce a potential suitable site and most suitable site.

\section{RESULT AND DISCUSSION}

The most suitable solid waste disposal site of the study area is selected by using GIS multi-criteria evaluation and overlay analysis. Site selection criteria that are considered for this research where evaluated individually and the results are combined as overlay to produce map of most suitable disposal site.

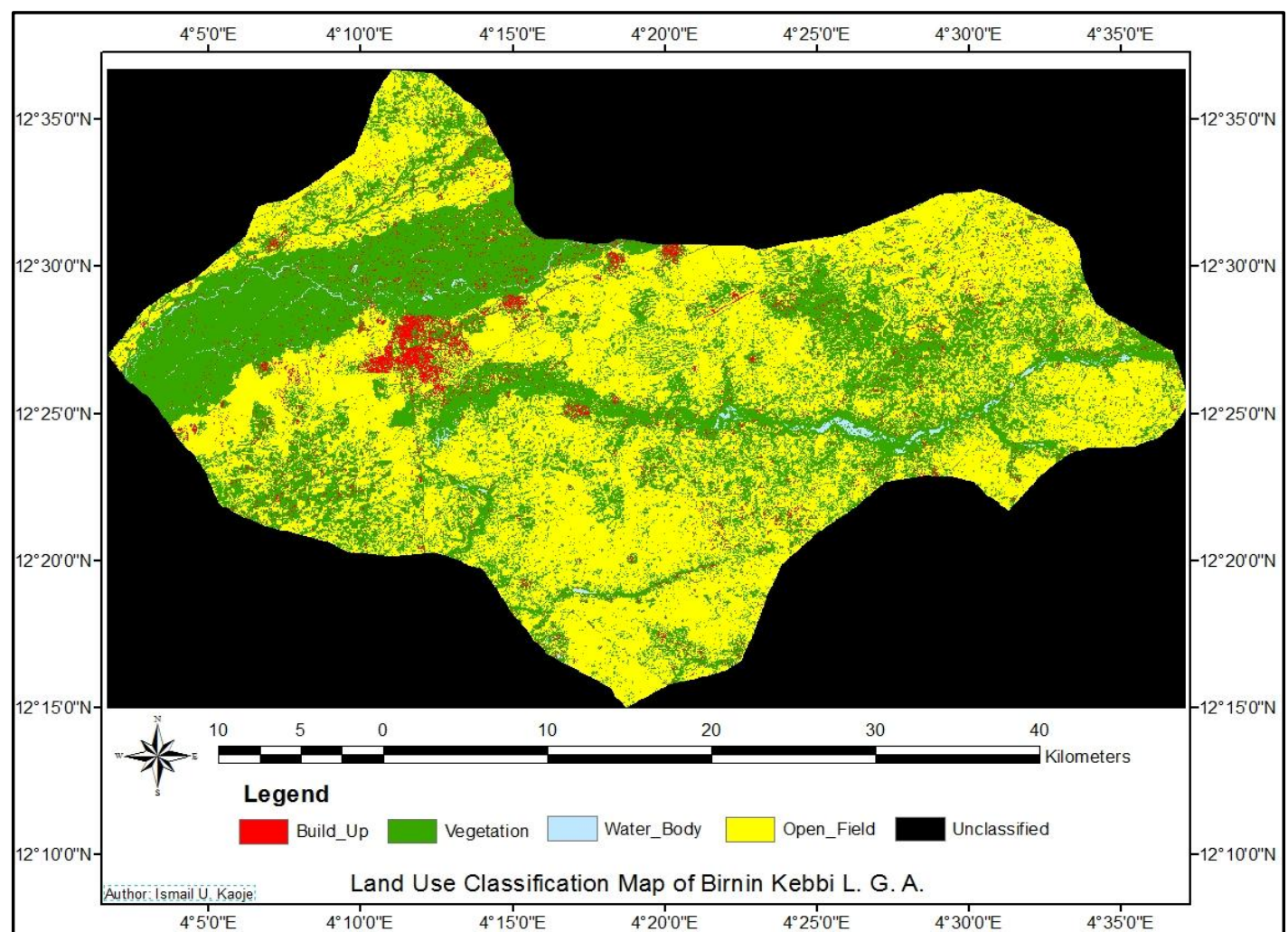

Figure 2: Land cover/land use classification of the study area

Fig. 2, shows land cover/land use classification map of the study area. Only less than $10 \%$ of the total land cover is built-up area and about $40 \%$ is for vegetation while open field that can be used for many purposes is more than $50 \%$ of the total land cover. In order to find out the most suitable site for solid waste disposal in the study area, the criteria adopted for this research are discuss below.

4.1Build-up areas

The first site selection criterion in this research is 1500 meters away from build-up areas. The term Build up area in this research refers to any area on which buildings and other social structures except transport route are present. These build up areas are parks, hospitals, markets, villages, schools airports, sport centres, and residential and non-residential buildings. 


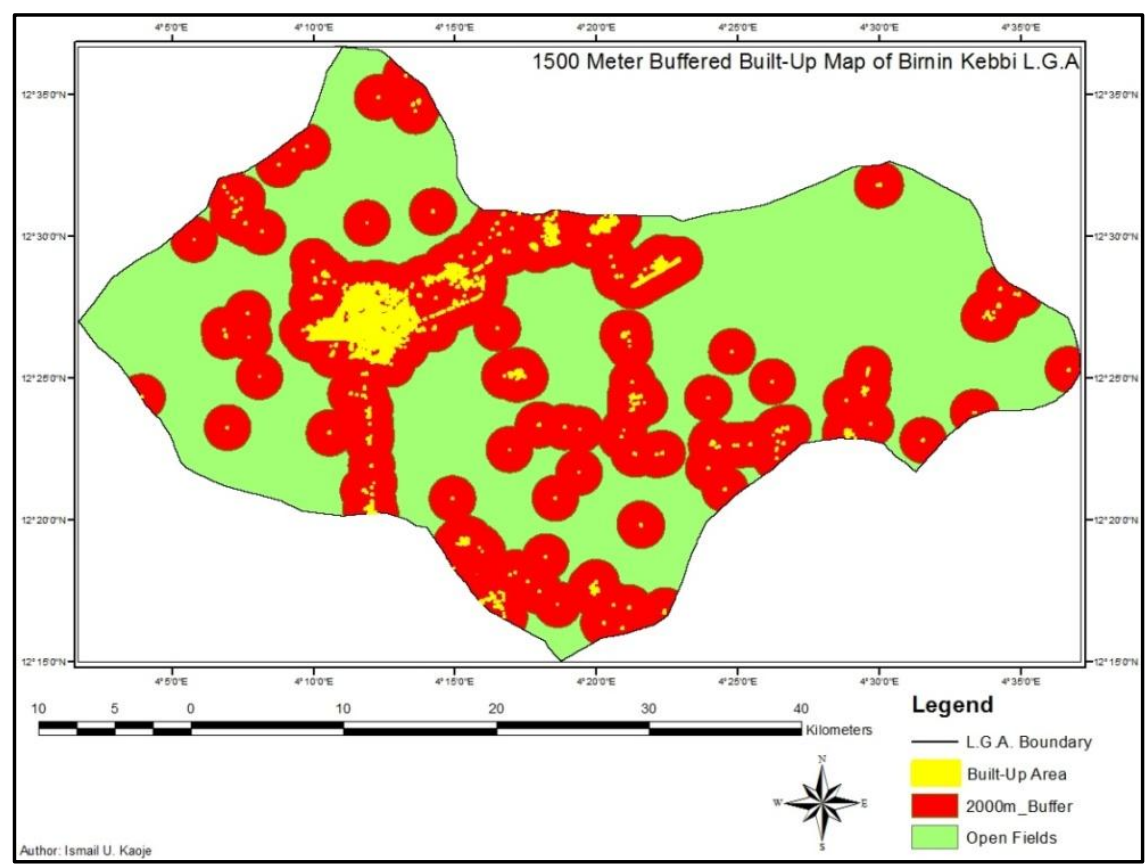

Figure 3: Buffered Built-up map of the study area

An analysis is carried out in GIS environment to find areas that are 1500 meters away from all built-up area. As shown in figure 3, built-up areas of the study area are buffered by $1500 \mathrm{~m}$. This means that areas that are within the buffered zones are unsuitable or restricted for disposal of waste. The purpose is to avoid any form of pollution to residential or dwelling areas. According to Environmental Protection Agency 2006, landfill/disposal site should not be placed closed to population. The disposal site should be at least 500 meters away from people (Bolasooriya, et al 2014). This prevents odour complaints, disease outbreak, noise complaints, scavenging, rodents and other animals' complaints, and decreased property value.

\subsection{Hydrological Criteria}

Surfaces water body is a natural resource that is very vital to humans and other animals on earths. Therefore, to avoid pollution of water surfaces, landfill/disposal site must not be in an area where it can affect or pollute water surfaces. As shown in figure 4 water surfaces such as river and streams of the study area were buffered at a distance of 300 meters to avoid all forms of water pollution. Landfill/disposal site close to surface water body lead to "effects on water quality, quantity and aquatic habitat loss, disturbance or alteration (Environmental Protection Agency (EPA) 2006).

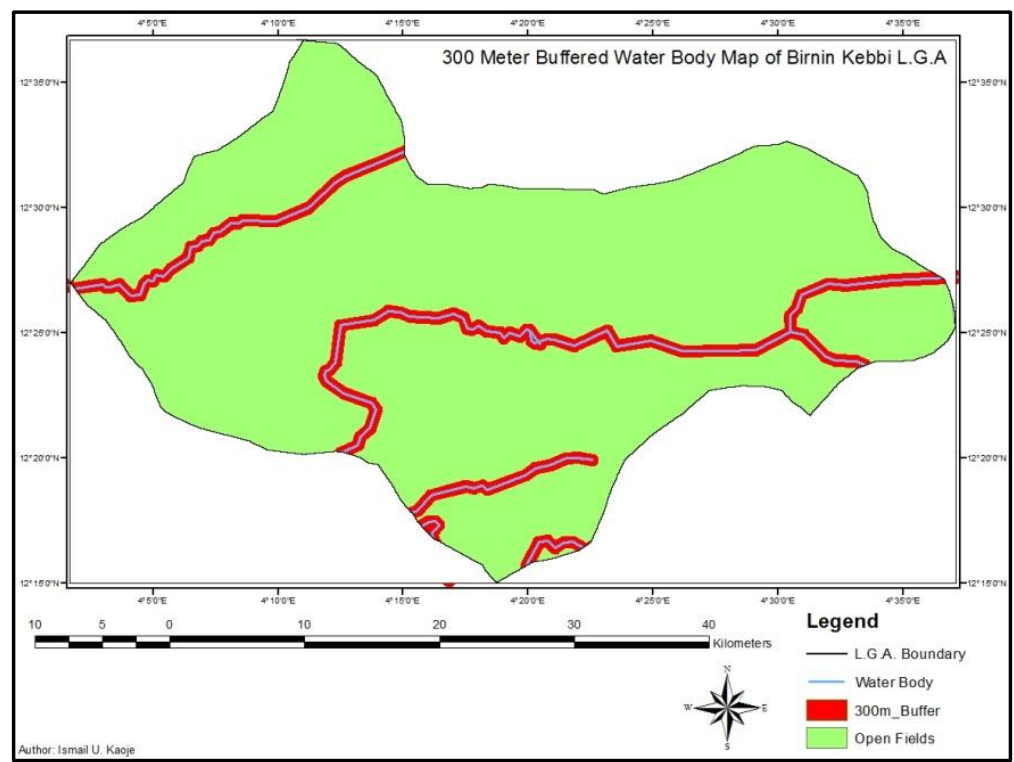

Figure 4: Buffered Water body map of the study area 


\subsection{Road network criteria}

Solid waste disposal must not be far away from transport route in order to facilitate transportation and to reduce relative cost of transportation. But it is also important to give adequate consideration to aesthetics values and human health. As shown in figure 5, 200 meters buffer is considered along all major transport routes in the study area. Keeping disposal site/landfill at least 200 meters away from the road network significantly reduce noise, traffic congestions and road damage from heavy vehicles that are usually involve in solid waste transportation. Thereby causing inconveniences for other road users.

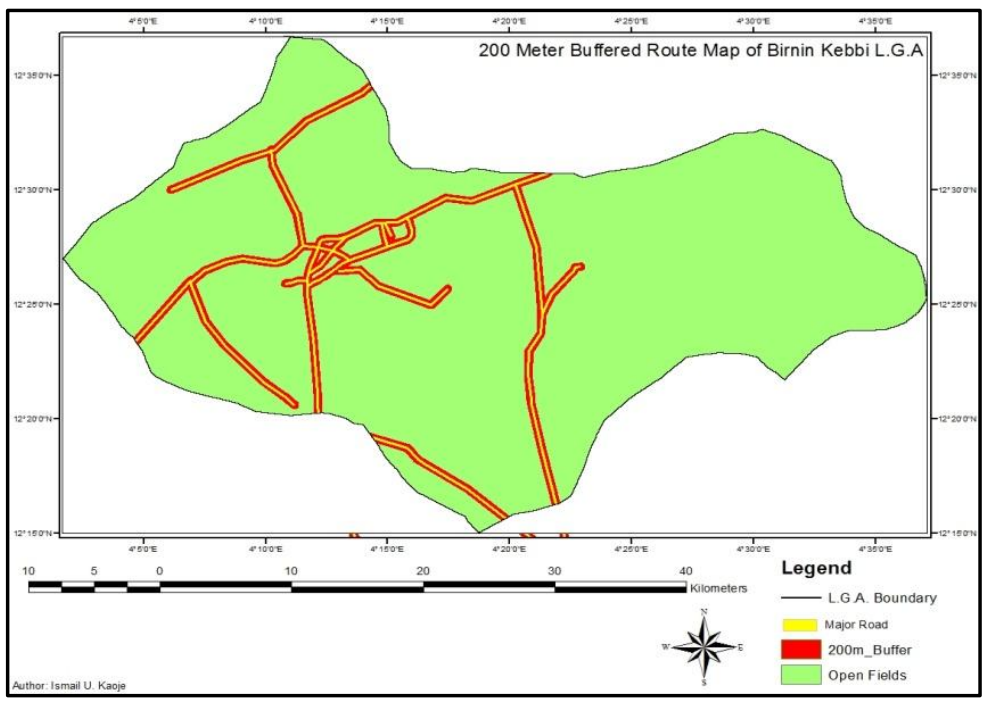

Figure 5: Buffered road map of the study area

\subsection{Vegetation criteria}

Agricultural land is a land cover used for agricultural purposes, particularly production of crops that produce food for humans. The production of food is very vital for the survival of man on earth. Therefore, such lands that are used for agricultural purposes are needs to be saved and protected from contamination. Likewise, forest reserves are land covered with trees and other woody vegetations where commercial harvesting of wood products is prohibited in order to capture element of biodiversity and to protect human environment from environmental disasters such as erosion, desertification, and global warming. So, it becomes necessary to keep solid waste disposal site/landfills away from both agricultural land and forest reserve areas (NTEPA 2013). As shown in figure 6,200 meters buffer is considered around both forest reserves and agricultural land areas of the study area. This means that land areas that are less than 200 meters away are indentified as unsuitable area for solid waste disposal.

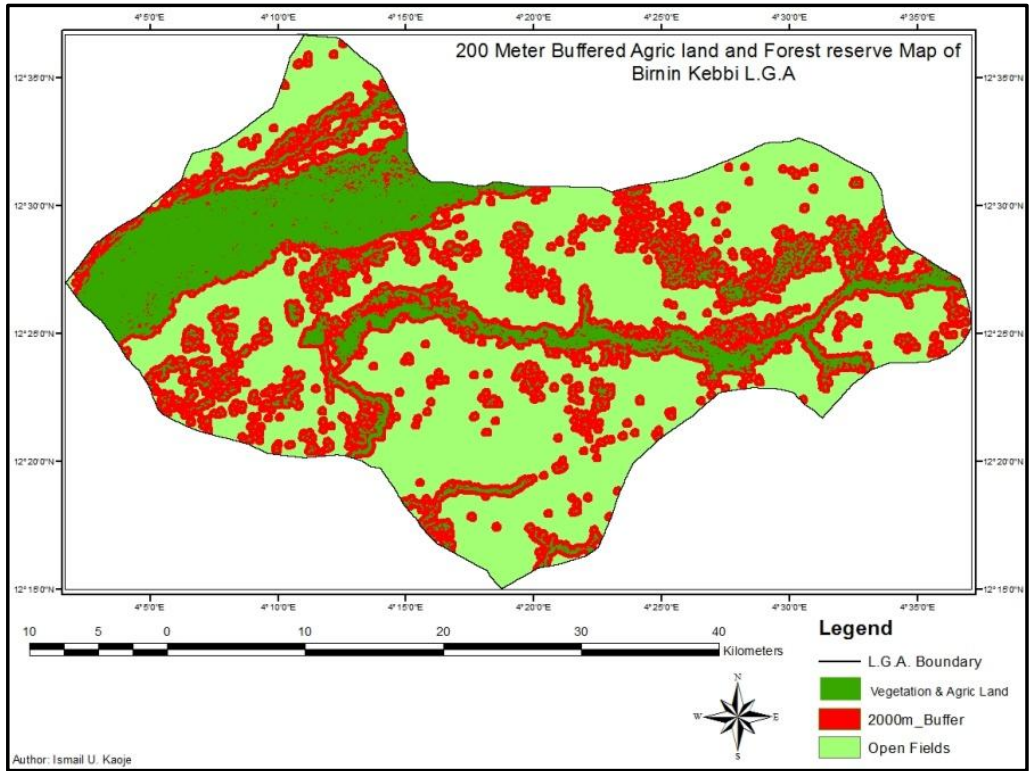

Figure 6: Buffered Forest and Agric land map of the Study area 


\subsection{Geologic criteria}

The geological criteria considered suitable for dumps are soil with relatively low rate permeability and soil with very low permeability. Soil type affects the rate of infiltration in the water table. "Due to risk of offsite movement of leachate and landfill gas, landfills should not be sited in areas with the high permeability soils" (UNEP 2005).

The major geological characteristic of Birnin Kebbi is dominated by two formations Precambrian Basement Complex and young sedimentary rocks. The Basement Complex region is composed of old volcanic and metamorphic rocks such as granites, schists, gneisses, quartzites and migmatites. The sedimentary region consists of rocks whose ages range from the Cretaceous to the Eocene. These are rocks from Gwandu group (that consists of massive clay grits interbedded with sandstone) and Rocks of Rima group that consists of pebbly grits, sand stones and clays, mudstones and siltstones (Online Nigeria, 2003).

For the purpose of this research, geological characteristics of Birnin Kebbi is categorized into three distinct classifications; soil with high rate of permeability (Sand, Sandstones, Gravel, Limestone) are considered unsuitable for solid waste disposal/landfills while soils with medium rate of permeability (Silt, Granites, Siltstones) and low rate permeability (clay, mudstones, gneisses, pebbly clay) are considered fairly suitable and optimal respectively. The three distinct classifications are designated in figure 7.

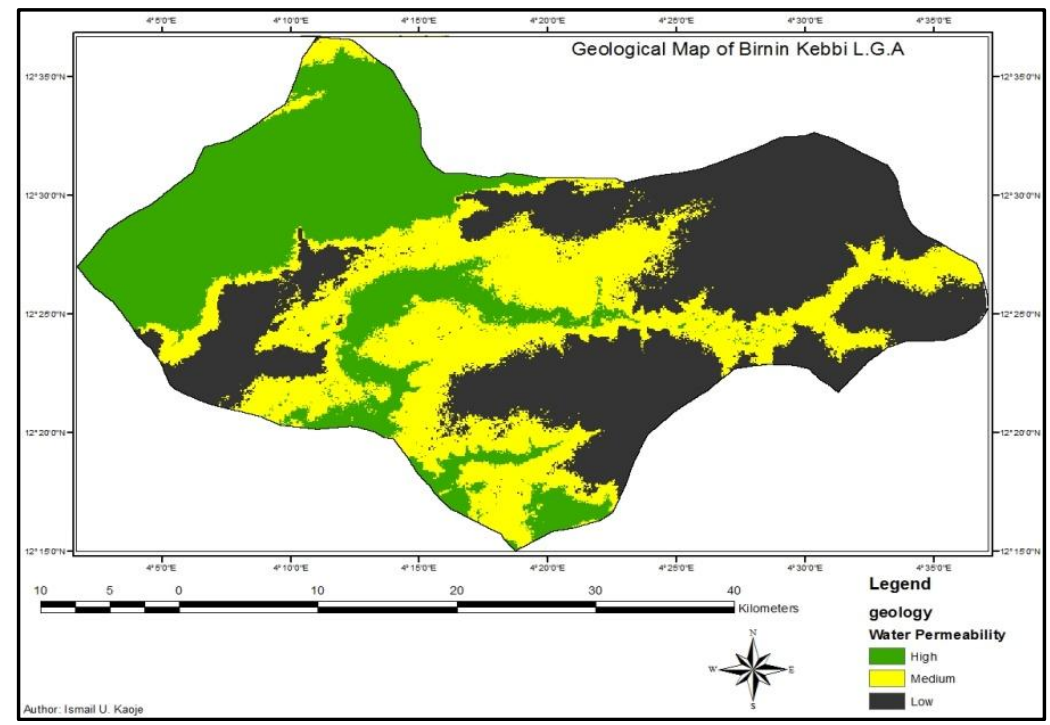

Figure 7: Water Permeability map

\subsection{Overlay Analysis}

Fig. 8 shows the overlay analysis of buffered areas (build-up, water body, road, vegetation) and water permeability map of the study area. The purpose of this analysis is to determine the available area that can be used as a disposal site. The buffered areas are highly unsuitable and they are classified as restricted areas for disposal of any kind of waste. Areas with high rate of permeability are unsuitable and are also classified as restricted areas.

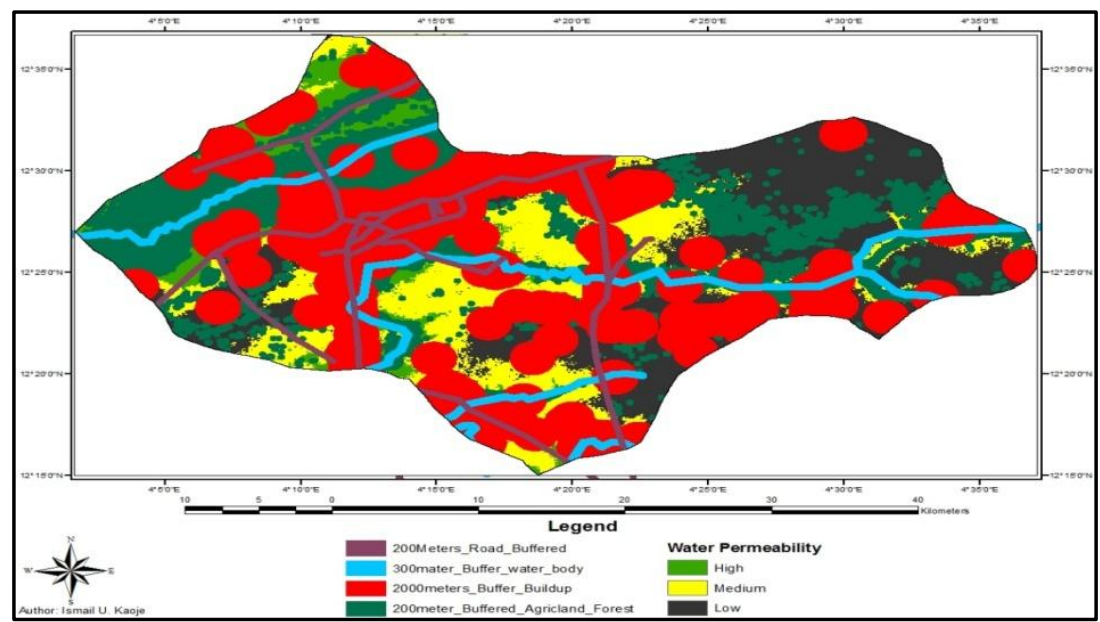

Figure 8: Overlay Map showing buffered (restricted) areas on Geological map 


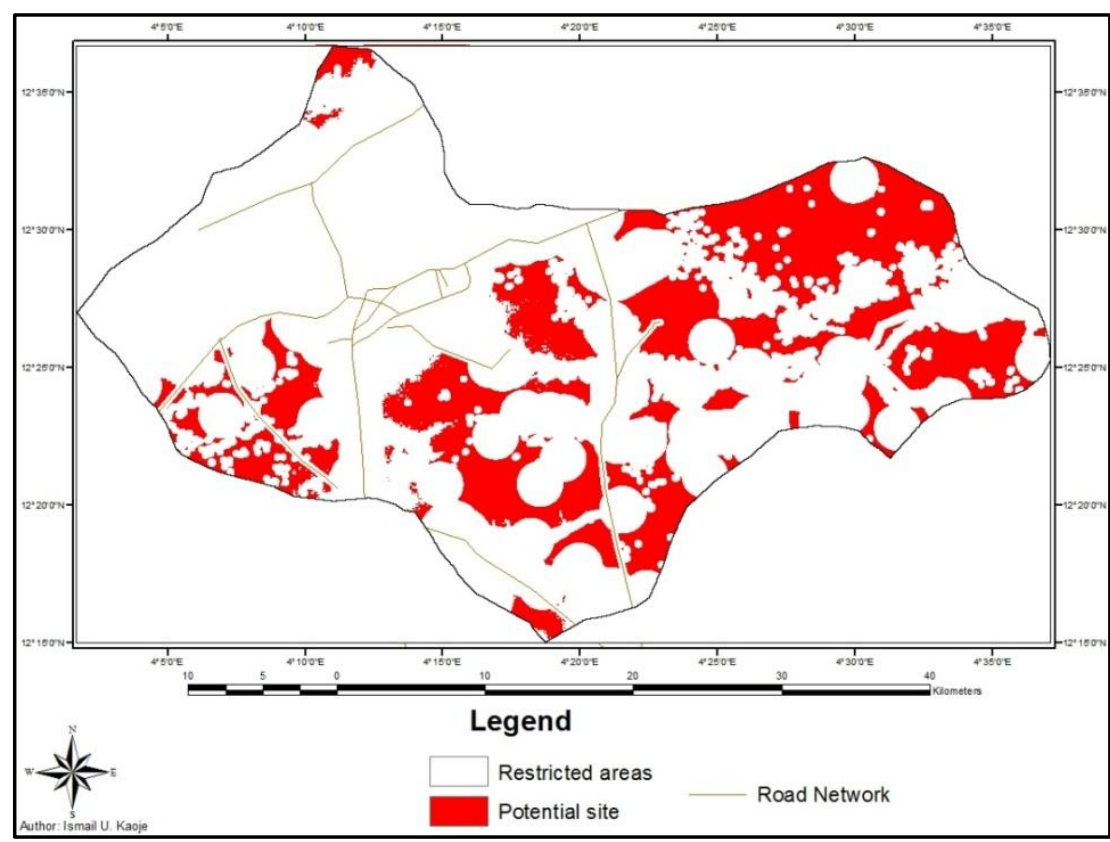

Figure 9: Potential site and route connectivity

As shown in figure 9. Restricted areas, that is buffered areas and areas with high rate of water permeabilty were erase using ArcGIS 10.1 Geoprocessing tools. This is to reveal the available areas that can be used as potential site for solid wate disposal. The unerase areas are identified as potential suitable site.

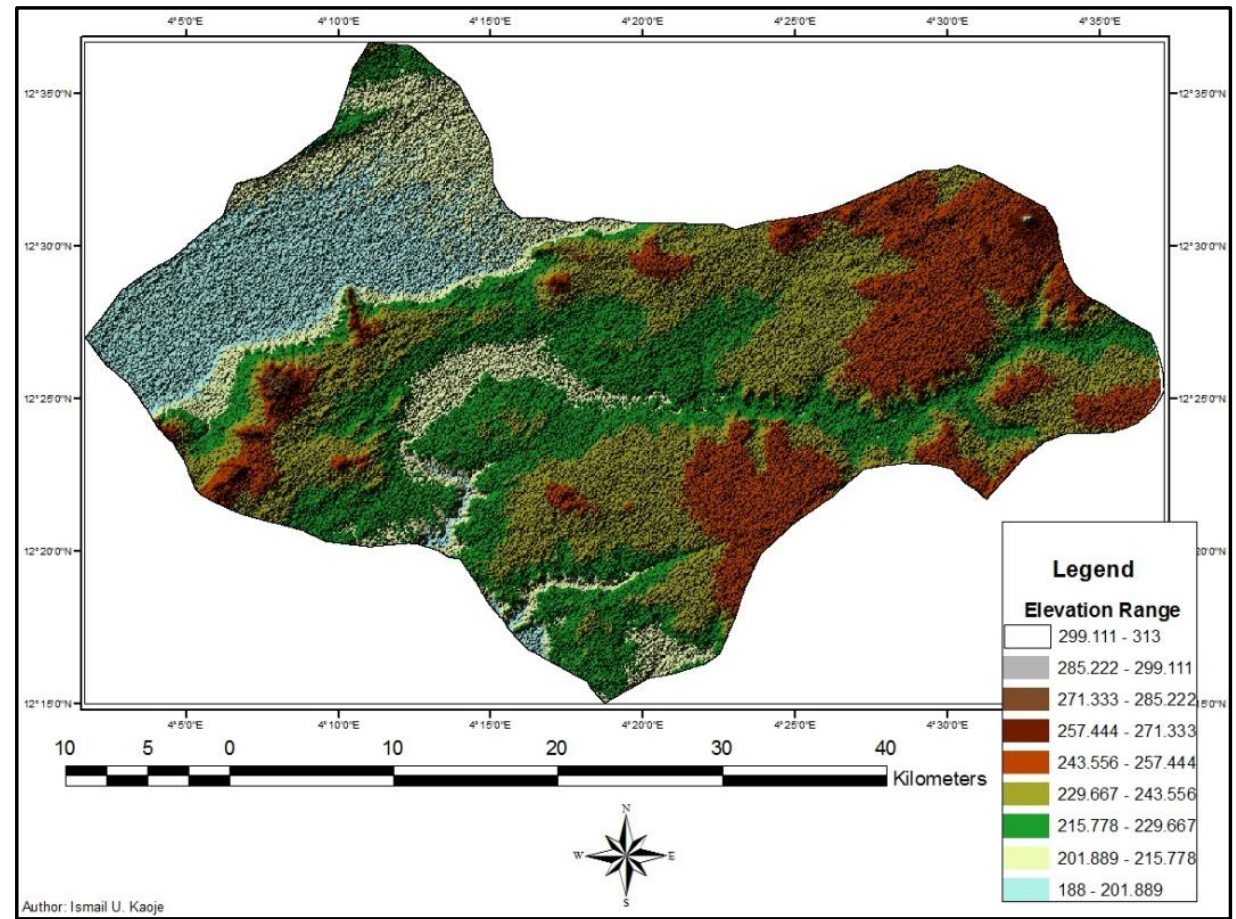

Figure 10: Triangulated Irregular Network map of the study area

Elevation is an important parameter in the identification of landfill site (Ayo and Ibrahim 2011 pp.5). Fig. 10 shows triangulated irregular network (TIN) map. It was generated from SRTM data of the study area in ArcMap 10.1. The map shows relief (elevation) and topographical characteristics of the study area. The elevation of the study area ranges between 180 and 315 meters above mean sea level. Areas with elevation range between $200 \mathrm{~m}$ to $250 \mathrm{~m}$ are considered suitable while areas below and above it ate unsuitable. This is because most areas that are between the ranges of $200 \mathrm{~m}$ to $250 \mathrm{~m}$ are flat and un-sloppy areas. Furthermore, flat surfaces are more suitable for landfill site than areas that are on a steep (UNEP 2005). 


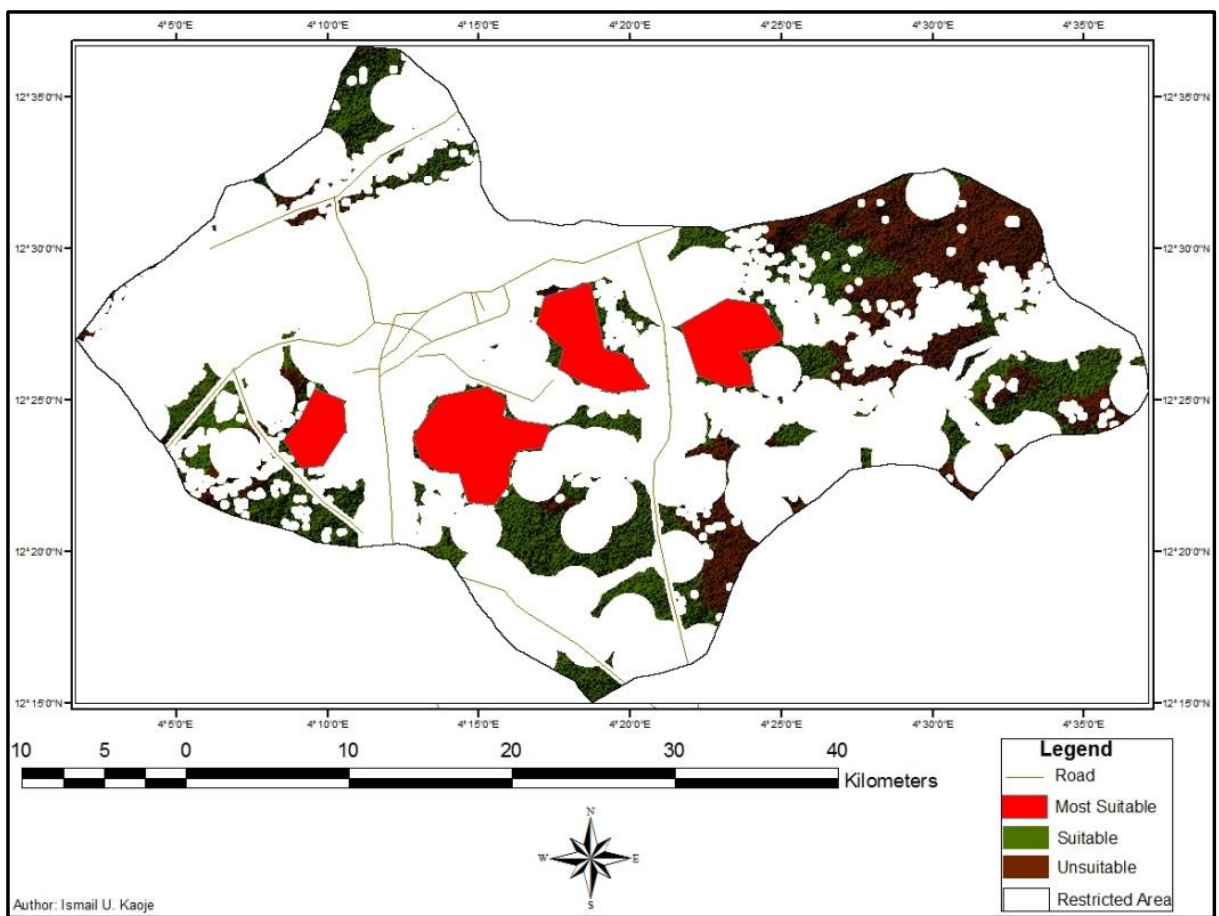

Figure 11: Map of Birnin Kebbi showing the most suitable landfill site

Fig.11 is the overlaid analysis of figure 9 and figure 10. Restricted areas, unsuitable, suitable and most suitable areas were clearly identified. Restricted areas were erased from the map. They are highly unsuitable site for any kind of waste disposal because dumping waste in these areas may directly or indirectly affect the urban population of the study area. Unsuitable areas are potential site but they are located on slopes. Suitable site are areas that pass all criteria for solid waste disposal adopted for this research among which the most suitable site were identified. Most suitable sites are sites that can easily be access by route and larger in size that the rest of the suitable site.

\section{CONCLUSION}

The study integrate Remote Sensing (RS) and GIS multi-criteria methods in analysing and finding out areas that are suitable for solid waste disposal in the study area. Its reveal that GIS and RS can be use in finding the most suitable site for solid waste disposal. It also shows that GIS and RS can be adopted by authorities involve in solid waste management to reduce their operational cost, save time and properly manage waste disposal. However, improper management of solid waste can lead to unhealthy environmental challenges and economical suffererings. Its implication to human health and environmental sustainability need to be properly addressed, especially in the study area where there is no permanent waste disposal site. Furthermore, this research achieved it purpose by successfully identifying areas that are suitable for solid disposal in the study area, based on the United Nations Environmental programme (UNEP) 2005 criteria for solid waste disposal.

\section{REFERENCES}

[1] Abdullah, R. B. Solid Waste Management Practices in Kebbi State, Nigeria:Problems and Prospect. International Refereed Journal of Engineering and Science, 2(12), 2013 48-54 Retrieved from http://www.irjes.com/Papers/vol2issue12/G02124854.pdf

[2] Ayuba, K. A. and Manaf, L. A, Current Status of Municipal Solid Waste Management Practise in FCT Abuja. Research Journal of Environmental and Earth Sciences, 5(6), 2013, 295-304. Retrieved from http://maxwellsci.com/print/rjees/v5-295-304.pdf

[3] Bolasooriya, et al (2014). Solid Waste Disposal Site Selection for Kandy District, Sri Lanka Integrating GIS and Risk Assessment. International Journal of Scientific and Research Publications, 2014, 4(10). Retrieved from http://www.ijsrp.org/research-paper-1014/ijsrp-p3420.pdf

[4] Environmental Protection Agency, (2006). EPA Landfill Manuals: Manual on Site Selection. Draft for Consultation. Retrieved from http://testweb.epa.ie/pubs/consultation/Landfill\%20Manual\%20-\%20Site\%20Selection.pdf

[5] Kabite, G., Suryabhagavan, K. V. and Sulaiman, H. (2012). GIS-Based Solid Waste Landfill Site Selection in Addis Ababa, Ethiopia. International Journal of Ecology and Environmental Sciences, 38, 2012. 59-72. Retrieved from http://www.nieindia.org/Journal/index.php/ijees/article/view/68 
[6] Nkwunonwo, U. C. and Okeke F. I. (2013). GIS-based production of digital soil map for Nigeria. Ethiopian Journal of Environmental Studies and Management, 6(5). Retrieved from http://www.ajol.info/index.php/ejesm/article/view/93441

[7] NPC (2010). Federal Republic of Nigeria:2006 Population and Housing Census. Retrieved from http://www.population.gov.ng/index.php/publications/140-population-distribution-by-sex-state-lgas-and-senatorialdistrict-2006-census-priority-tables-vol-3

[8] NTEPA (2013). Guidelines for the Siting, Design and Management of Solid Waste Disposal Sites. Retrievedfromwww.ntepa.nt.gov.au/_data/assets/pdf_file/0020/136460/siting_design_landfills.pdf

[9] Online Nigeria, (2003). $\quad$ Physical $\quad$ Setting. $\quad$ Retrieved from http://www.onlinenigeria.com/links/kebbiadv.asp?blurb=300

[10] Ujoh, F, kwabe I. D. and Ifatimehin O. (2010). Understanding urban sprawl in the Federal Capital City, Abuja: Towards sustainable urbanization in Nigeria. Journal of Geography and Regional Planning, 3, 106-113. Retrieved from http://www.academia.edu/799021/Understanding_Urban_Sprawl_in_the_Federal_Capital_City_Towards_Sustainabl e_Urbanization_in_Nigeria

[11] UNEP. (2005). Solid waste management: United Nations Environment Programme. Retrieved from http://www.unep.or.jp/Ietc/Publications/spc/Solid_Waste_Management/Vol_I/Binder1.pdf

[12] USGS (2015). U.S. Geological Survey webpage. Available at http://www.usgs.gov/ 